\title{
PROTEROZOIC MICROFOSSILS FROM THE SEDIMENTARY ROCKS OF THE LAPPAJÄRVI IMPACT CRATER
}

\begin{abstract}
ANNELI UUTELA
UUTELA, ANNELI, 1990: Proterozoic microfossils from the sedimentary rocks of the Lappajärvi impact crater. Bull. Geol. Soc. Finland 62, Part 2, 115-121. The Proterozoic microbiota of acritarchs is reported from the siltstone deposit of Lappajärvi. Diversity is low, with sphaeromorphs dominating the taxa, which also includes some coenobial and ovoidal specimens and a fragment of filament. The undisturbed structures and horizontal layering of the sedimentary rocks and the good state of preservation of the microfossils indicate that the siltstone occupies the marginal zone of the meteorite impact.
\end{abstract}

Key words: sedimentary rocks, microfossils, acritarch flora, meteor craters, Proterozoic, Lappajärvi, Finland

Anneli Uutela: Geological Survey Of Finland. SF-02150 Espoo, Finland.

\section{Introduction}

Lake Lappajärvi, western Finland (Fig. 1.), occupies a circular basin long interpreted as the crater of an ancient volcano (Eskola 1921, cf. Cohen 1990, Nicolaysen 1990). However, from petrological evidence it would appear to be an astrobleme (Svensson 1968, Lehtinen 1970, 1976, 1990. The ${ }^{40} \mathrm{Ar}-{ }^{39} \mathrm{Ar}$ age of the kärnäite is 77 Ma (Jessberger \& Reimold 1980), but palaeomagnetic studies suggest an age of $>200 \mathrm{Ma}$ (Pesonen et al. 1984). Lehtovaara (1982) points out that the crater should be considerably older because of the slow rate of erosion of the Fennoscandian Shield.

The Geological Survey of Finland drilled a hole in the central depression (Pipping 1989, Kivekäs et al. 1990) and later another in the rim, where a sequence of sedimentary rocks was penetrated and sampled (Pipping \& Vaarma 1990). The following gives the results of biostratigraphic dat- ing based on the acritarch assemblage of the sedimentary rocks.

\section{Lithostratigraphy}

At the site of drill hole K 52/302, sedimentary rocks attaining a total thickness of about 18 metres were intersected between depths of 74.35 and $92.40 \mathrm{~m}$, between the overlying Late Pleistocene sediments and basement rocks consisting of weathered mica gneiss.

The basal part of the sedimentary rocks is a 4.10-m-thick yellowish conglomerate with wellrounded quarz grains. The sequence continues as a $30 \mathrm{~cm}$ layer of claystone, which in turn is overlain by fine-grained greenish sandstone. There is a 10 to $20 \mathrm{~cm}$ thick greenish, horizontally layered siltstone with some glaukonite grains at a depth of $82.30 \mathrm{~m}$. The colour of the siltstone is reddish and light brown, and at a depth of $81.00 \mathrm{~m}$ it 


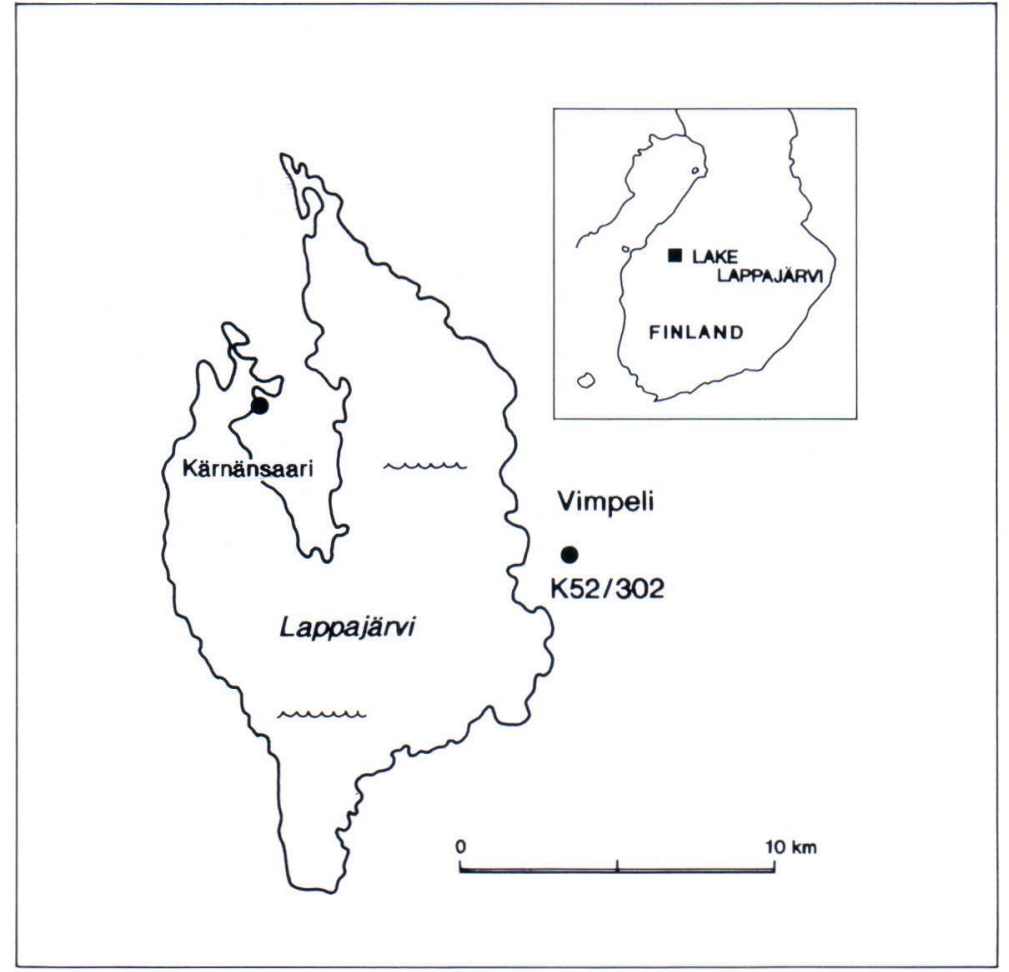

Fig. 1. The drilling site at Vimpeli, east of Lake Lappajärvi. turns ochre. The dip of the layers is ca. $60^{\circ}$. The uppermost part of the sedimentary rocks (74.35$82.30 \mathrm{~m}$ ) is greenish siltstone, with sharply angular feldspar grains and $0.8-1.2 \mathrm{~mm}$ thick undulating layers of sand (Fig. 2.).

Thirteen samples were investigated for the purpose of biostratigraphic dating. The samples were processed using $\mathrm{HF}$ and $\mathrm{HCl}$. Sodium polytungstate (specific gravity $=2.2 \mathrm{~g} / \mathrm{cm}^{3}$ ) was used for gravity separation. The samples were mounted with glycerine jelly. Light microscopy was performed with a Leiz Wetzlar Orthoplan research microscope, and photographs were taken on Kodak Panatomic-X 32 film using a Leica camera.

\section{Microfossils}

The organic-walled microfossils of the Lappajärvi sedimentary deposit belong to the Group Acritarcha Evitt 1963. Acritarchs were found only in the middle part of the strata studied. The diversity is low, and psilate sphaeromorphs are the most common in the present material. The specimens are generally well preserved. However, acritarchs from underlying weathered mica gneiss are poorly preserved, being strongly thermally altered and deformed due to mechanical stress.

Simple sphaeromorphs (Pl. I:1-2) (Leiosphaeridia spp.) dominate the microbiota. The vesicle is spherical to sub-spherical, thin-walled and psilate or slightly shagrinate and the largest ones are folded. The specimens are usually light yellow or light brown in colour. Their diameter ranges $7-416 \mu \mathrm{m}$, mode $15-24 \mu \mathrm{m}$ (depth levels $83.00-95.55 \mathrm{~m}, \mathrm{n}=549$ ).

Sphaeroids 7-66 $\mu \mathrm{m}$ in diameter may be identified as species of Leiosphaeridia asperata (Naumova) Lindgren 1982 or Leiosphaeridia crassa (Naumova) Yankauskas 1989, with many synonyms, both including the species Kildinella hyper- 
Vimpeli K 52/302

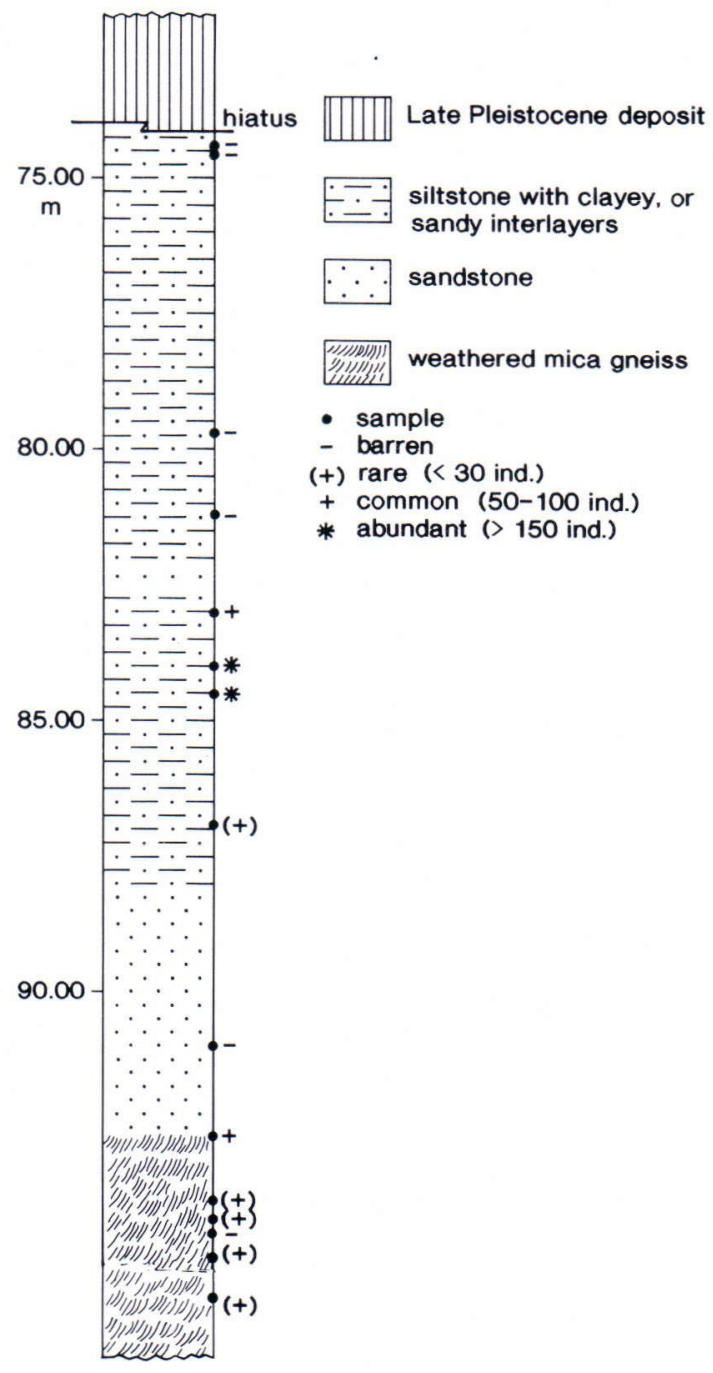

Fig. 2. The drill core sequence from the Lappajärvi sedimentary rocks.

boreica Timofeev 1966. The time range of all these is Late Riphean to Cambrian (Lindgren 1982, Yankauskas et al. 1989).

The species Leiosphaeridia tenuissima Eisenack 1958 /Leiopsophosphaera giganteus Schepeleva 1963 measures $75-200 \mu \mathrm{m}$, and the species Kildinella jacutica Timofeev $1966 \mathrm{mea}-$ sures $150-250 \mu \mathrm{m}$, both with many synonyms.
The time range of the former is Late Riphean to Ordovician (Yankauskas et al. 1989) and that of the latter Riphean (Timofeev 1966, 1969).

Large thin-walled psilate sphaeromorphs have been recorded by Peat et al. (1978) (up to $600 \mu \mathrm{m}$ ) from Roper Group, Australia and by Horodyski (1980) (up to $440 \mu \mathrm{m}$ ) from Little Belt Mountains, Montana, Canada.

Thick-walled sphaeromorphs (PI. I:3) are the next most common. The vesicle is spherical to subspherical and thick-walled $(2-3 \mu \mathrm{m})$ with an irregularly meshy surface. The specimens range from light yellow to dark brown in colour. Their diameter is $14-22 \mu \mathrm{m}$, mean $17.7 \mu \mathrm{m}$, bimodal $15 \mu \mathrm{m}$ and $18 \mu \mathrm{m}(\mathrm{n}=27$, depth levels 83.00$86.85 \mathrm{~m}$ ).

Only a few medium-sized thick-walled sphaeromorhps are reported from the Proterozoic material. Manum (1967) has recorded Late Precambrian Form F with a porous surface from southern Norway.

The material includes three coenobia of thinwalled psilate subspherical vesicles (Pl. I:4). The diameter of a single vesicle is $10 \mu \mathrm{m}$ (depth levels $84.00-84.45 \mathrm{~m}$ ) and $10-20$ vesicles are loosely and irregularly connected together (Synsphaeridium sp.). The vesicle is transparent or light yellow in colour.

The specimen resembles the psilate Synsphaeridium sorediforme Timofeev (1959) 1966 but is smaller in size. In Synsphaeridium conglutinatum Timofeev (1959) 1966 the vesicle has a shagrinate surface. Single vesicles resemble small individuals of Leiosphaeridia asperata, which, according to Lindgren (1982), includes coenobia. However, the vesicles are spherical and larger $(34-40 \mu \mathrm{m})$ and form regular coenobia, although some are in clusters composed of a few vesicles. Eisenack (1965) has reported Palaeozoic Synsphaeridium species with an ornamented surface.

A similar psilate, Synsphaeridium sp., has also been recorded as Late Riphean: from Finland, Muhos formation (Tynni \& Siivola 1966, Tynni 1978, Tynni \& Uutela 1984); as Riphean to Ear- 
ly Palaeozoic: from the U.S.S.R. (Yankauskas et al. 1989); and as Vendian: from Finland, Hailuoto (Tynni \& Donner 1980, Johanson 1988) and Taivalkoski (Tynni \& Uutela 1985).

The material also contains one asymmetrically ovoidal species (Pl. I:5) (?Archaeoellipsoides sp.), with one side straight, and one curved and rounded poles. The surface is shagrinate and it is sepia in colour. It is $14 \mu \mathrm{m}$ wide and $30 \mu \mathrm{m}$ long (depth level $84.45 \mathrm{~m}$ ).

The specimen, having asymmetrical sides, differs from the genera Brevirtichoides Yankauskas 1980 and Leiovalia Eisenack 1965. The ellipsoidal to pear-shaped and sausage-shaped $\mathrm{Ar}$ chaeoellipsoides grandis has a smooth surface (Horodyski \& Donaldson 1980).

One fragment of an empty hollow filament (Pl. I:6) is reported in the present material. It is thinwalled, unbranched and non-septate. The surface of the filament is psilate, but some parts are slightly and irregularly rugose. Its length is ca. $120 \mu \mathrm{m}$ and width $8 \mu \mathrm{m}$ (depth level $86.85 \mathrm{~m}$ ). The filament differs from the rugose Siphonophycus keston Schopf 1968. Knoll (1984) has described Siphonophycus sp. (width 5-45 $\mu \mathrm{m})$ from Late Precambrian deposits in Svalbard, Spitzbergen. Tynni and Uutela (1984) have described similar unbranched filaments from the Late Riphean Muhos formation (width 8-13 $\mu \mathrm{m})$. Uutela (1986) has recorded one fragment (width $20 \mu \mathrm{m}$ ) from Ryydys, and Johanson (1988) many from the Vendian Hailuoto formation $(5-20 \mu \mathrm{m})$.

Similar filaments $9 \mu \mathrm{m}$ wide are very common in the Vendian Taivalkoski siltstone. In Canada, Hofmann and Aitken (1979) have described similar filaments of equal and greater width (max. $62 \mu \mathrm{m})$ from Late Riphean deposits, and Hofmann (1984) from Late Riphean to Early Cambrian deposits.

\section{Discussion}

The present material is characterized by a low diversity assemblage dominated by only a few taxa. The Late Riphean assemblage is dominated by sphaeromorphic acritarchs (including Leiosphaeridia asperata, Kildinella hyperborei$c a$ and Synsphaeridium sp.), which are also present in the Early Vendian. However, Octoedryxium and Vandalosphaeridium, which are indicative taxa of the Early Vendian, are absent from the present material, as is Bavlinella faveolata, which indicates the Middle Vendian (Varangerian) glacial epoch (Vidal \& Knoll 1982, 1983).

A similar assemblage, although more diverse, has been described from the Precambrian Muhos formation (Tynni \& Siivola 1966, Tynni 1978, Tynni \& Uutela 1984). The formation has been dated with microfossils to $1200 \mathrm{Ma}$ (Tynni \& Uutela 1984), although K-Ar and Rb-Sr determinations give an age of 1300-1400 Ma (Simonen 1980).

The microfossil assemblage in the Visingsö Group in Sweden is also more diverse (Vidal 1974, 1976), its Late Riphean age being dated to ca. $800 \mathrm{Ma}$ (Vidal \& Bylund 1981, Vidal \& Siedlecka 1983) and its Vendian age to ca. $700 \mathrm{Ma}$ (Vidal 1976).

In the Vendian Hailuoto formation (ca. 600 Ma) the diversity of species is marked. The taxa includes not only simple spherical and filamentous forms but also cylindrical (Volyniella) and multicellular filaments (Oscillatoriopsis) (Tynni \& Donner 1980, Johanson 1988), as in the Taivalkoski formation (Tynni \& Uutela 1985).

Although the material lacks all indicator species, the Vimpeli sedimentary deposit is probably as old as the Muhos formation, or slightly younger, i.e. Late Riphean, but it is older than the Vendian deposits at Hailuoto and Taivalkoski.

The low-diversity assemblages dominated by one or a few taxa indicate inshore, particularly lagoonal, environments (Vidal \& Knoll 1982). This finding is supported by the sedimentary structures. At that time, Lake Lappajärvi was an inshore, shallow marine or non-marine basin.

The largerly undisturbed structures and 
horizontal layering of the sedimentary rocks and the good state of preservation of the microfossils indicate that the basin was formed before the deposition of siltstone. The assemblage of acritarchs can be related with the Proterozoicum better than with later eras.

\section{References:}

Cohen, A.J., 1990. Lappajärvi could be cryptovolcanic! In: Pesonen, L. \& Niemisara, H. (eds.). Symposium on Fennoscandian Impact Structures, Espoo and Lappajärvi, Finland, May 29-31, 1990. Programme and Abstracts, Geological Survey of Finland, p. 58.

Eisenack, A., 1965. Mikrofossilien aus dem Silur Gotlands. Hystricosphären, Problematica. N. Jb. Geol. Paläont. Abh. 122, 257-274.

Eskola, P., 1921. Volcanic necks in Lake Jänisjärvi in Eastern Finland. Bull. Comm. géol. Finlande 55, 13 pp.

Hofmann. H.J. 1984., Organic-walled microfossils from the latest Proterozoic and earliest Cambrian of the Wernecke Mountains, Yokon. Geol. Surv. Canada, Paper 84-1B, Current Research, Part B, 285-297.

Hofmann, H.J. \& Aitken, J.D., 1979. Precambrian biota from the Little Dal Group, Mackenzie Mountains, northwestern Canada. Can. J. Earth Sci. 16, 150-166.

Horodyski, R.J., 1980. Middle Proterozoic shale-facies microbiota from the Lower Belt Supergroup, Little Belt Mountains, Montana. J. Palaeontol. 54:4, 649-663.

Horodyski, R.J. \& Donaldson, J.A., 1980. Microfossils from the Middle Proterozoic Dismal Lakes Group, Arctic Canada. Prec. Res. 11, 125-159.

Jessberger, E.K.\& Reimold, W.U., 1980. A Late Cretaceous ${ }^{40} \mathrm{Ar}-{ }^{39} \mathrm{Ar}$ Age for the Lappajärvi Impact Crater, Finland. J.Geophys. 48(2), 57-59.

Johanson, C., 1988. Hailuoto-formationens mikrofossil systematik och storleksfördelning. Unpublished manuscript. University of Helsinki, Department of Zoology. $62 \mathrm{p}$.

Kivekäs, L., Kukkonen, I. \& Paananen, M., 1990. Physical properties of kärnäite and related rocks in the Lappajärvi meteorite crater, Finland. In Pesonen, L. \& Niemisara, H. (eds.). Symposium on Fennoscandian Impact Structures, Espoo and Lappajärvi, Finland, May 29-31, 1990. Programme and Abstracts, Geological Survey of Finland, p. 20.

Knoll, A.H., 1984. Microbiotas of the Precambrian Hunneberg Formation, Nordaustlandet, Svalbard. J. Paleontol. $58,131-162$.
Acknowledgements. Mr Fredrik Pipping kindly supplied the material from Lappajärvi, and Drs. Jyrki Lehtovaara and Veli-Pekka Salonen made the lithological description of the core. Professor Gonzalo Vidal and Dr Risto Tynni read the manuscript and greatly improved it. Mrs Satu Moberg made the drawings. The English was corrected by Mrs Gillian Häkli. I wish to express my best thanks to all of them.

Lehtinen, M., 1970. New evidence for an impact origin of Lake Lappajärvi, western Finland. Bull. Geol. Soc. Finland 42, 89-93.

- 1976. Lake Lappajärvi, a meteorite impact site in western Finland. Geol. Surv. Finland. Bull. 282. 92 p.

- 1990. Petrology and mineralogy of the impact melt and breccias in the deep drill core, Lake Lappajärvi, western Finland. In Pesonen, L. \& Niemisara, H. (eds). Symposium on Fennoscandian Impact Structures, Espoo and Lappajärvi, Finland, May 29-31, 1990. Programme and Abstrats, Geological Survey of Finland, p. 19.

Lehtovaara, J.J., 1982. Palaeozoic Sedimentary rocks in Finland. Ann. Acad. Sci. Fennicae, A. III 133, 35 pp.

Lindgren, S., 1982. Algal coenobia and leiospheres from the Upper Riphean of the Turukhansk region, eastern Siberia. Stockholms Contributions in Geology 38(3), 35-45.

Manum, S., 1967. Microfossils from late Precambrian sediments around lake Mjøsa, Southern Norway. Norges Geologiske Undersökelse 251, 45-52.

Nicolaysen, L.O., 1990. An »internal» origin proposed for Siljan, Dellen and Lappajärvi structures. In Pesonen, L. \& Niemisara, H. (eds). Symposium on Fennoscandian Impact Structures, Espoo and Lappajärvi, Finland, May 29-31, 1990. Programme and Abstracts, Geological Survey of Finland, p. 50.

Peat, C.J., Muir, M.D., Plumb, K.A., McKirdy, D.M. \& Norvick, M.S., 1978. Proterozoic microfossils from the Roper Group, Northern Territory, Australia. BMR J. of Australian Geology and Geophysics 3, 1-17.

Pesonen, L.J., Pippping, F. \& Halls, H.C., 1984. Paleomagnetic study of the Lake Lappajärvi impact crater, western Finland. Terra Cognita 4, p. 371.

Pipping, F., 1989. Deep drilling within Lappajärvi meteorite impact crater. Geol. Surv. Finland, Special Paper 10, $9-10$.

Pipping, F. \& Vaarma, M., 1990. Lappajärvi impact crater, geology and structure. In Pesonen, L. \& Niemisara, H. (eds). Symposium on Fennoscandian Impact Structures, Espoo and Lappajärvi, Finland, May 29-31, 1990. Programme and Abstracts, Geological Survey of Finland, p. 18. 
Simonen, A., 1980. The Precambrian in Finland. Bull. Geol. Surv. Finland 304, 58 p.

Svensson, N.-B., 1968. Lake Lappajärvi, Central Finland: a possible meteorite impact structure. Nature 217, p. 438.

Timofeev, B.V., 1966. Mikropaleofitologiceskoe issledovanie drevnih svit. Akad. Nauk. SSSR. laboratorija geologii dokembrija. Nauka. Leningrad. 147 p.

- 1969. Sferomorfidy proterozoja. Akad. Nauk SSSR. Institut geologii i geochronologii dokembrija. Nauka. Leningrad. $146 \mathrm{p}$.

Tynni, $R$., 1978. Muhoksen muodostuman mikrofossiilitutkimuksen tuloksia. GTL. Tutkimusraportti No 30, 18 p.

Tynni, R. \& Donner, J., 1980. A microfossil and sedimentation study of the Late Pre-cambrian formation of Hailuoto, Finland. Geol. Surv. Finland Bull 311, 27 p.

Tynni, R. \& Siivola, J., 1966. On the Precambrian microfossil flora in the siltstone of Muhos, Finland. Bull. Comm. géol. Finlande 222, 127-133.

Tynni, R. \& Uutela, A., 1984. Microfossils from the Precambrian Muhos formation in Western Finland. Bull. Geol. Surv. Finland 330, 38 p.

- 1985. Myöhäis-prekambrinen ajoitus Taivalkosken savikivelle mikrofossiilien perusteella. (Summary: Late Precambrian shale formation of Taivalkoski in northern Finland.) Geologi 37(4-5), 61-65.

Uutela, A., 1986. Ryydyksen sedimenttikiven mikrofossiilit (Summary: A microfossil study of the sandstone of the Precambrian Ryydys, western Finland). Geologi 38, $206-210$.

Vidal, G., 1974. Late Precambrian microfossils from the basal sandstone unit of the Visingsö beds, South Sweden. Geologica et Paleontologica 8, 1-14.

- 1976. Late Precambrian microfossils from the Visingsö beds in southern Sweden. Fossil and Strata 9, 57 p.
Vidal, G. \& Bylund, T.G., 1981. Late Precambrian boulder beds in the Visingsö Beds, South Sweden. In Humbrey, M.I. \& Hurland, W.B.(eds). Earths Pre-Pleistocene Glacial Record. Cambridge University Press, 629-631.

Vidal, G. \& Knoll, A.H., 1982. Radiations and extinctions of plankton in the late Proterozoic and early Cambrian. Nature 297, 57-60.

- 1983. Proterozoic plankton. Geol. Soc. Am. Mem. 161, 265-277.

Vidal. G. \& Siedlecka, A., 1983. Planktonic, acid-resistant microfossils from the Upper Proterozoic Strata of the Barents Sea Region of Varanger Peninsula, East Finnmark, northern Norway. Norges Geologiske Undersökelse 382, 45-79.

Yankauskas, T.V., Mikhailova, N.S., German, T.N. Sergeyev, V.N., Abduazimova, Z.M., Belova, M.Yu., Burzin, M.B., Veis, A.F., Volkova, N.A., Golovionok, V.K., Grigorijeva, A.Ye., Kirjanov, V. V., Kozlova, Ye.V., Kolosov, P.N., Kraskov, L.N., Krylov, I.N., Luchinina, V.A., Medvedeva, A.M., Oqurtzova, R.N., Paskiavichene, L.T., Piatiletov, V.G., Rudavskaya, V.A., Sivertzeva, I.A., Stanevich, A.M., Treshchetenkova, A.A., Faizulina, Z.Kh., Chepikova, I. K., Shenfil, V.Yu., Shepeleva, E.D., Yaksin, M. S., 1989. Precambrian microfossils of the USSR (in Russian). Akad. Nauk. Institut Geologii i Geohronologii Dokembrija. Leningrad. $191 \mathrm{pp}$.

Received May 10, 1990

Revision accepted September 12, 1990 


\section{Plate I}
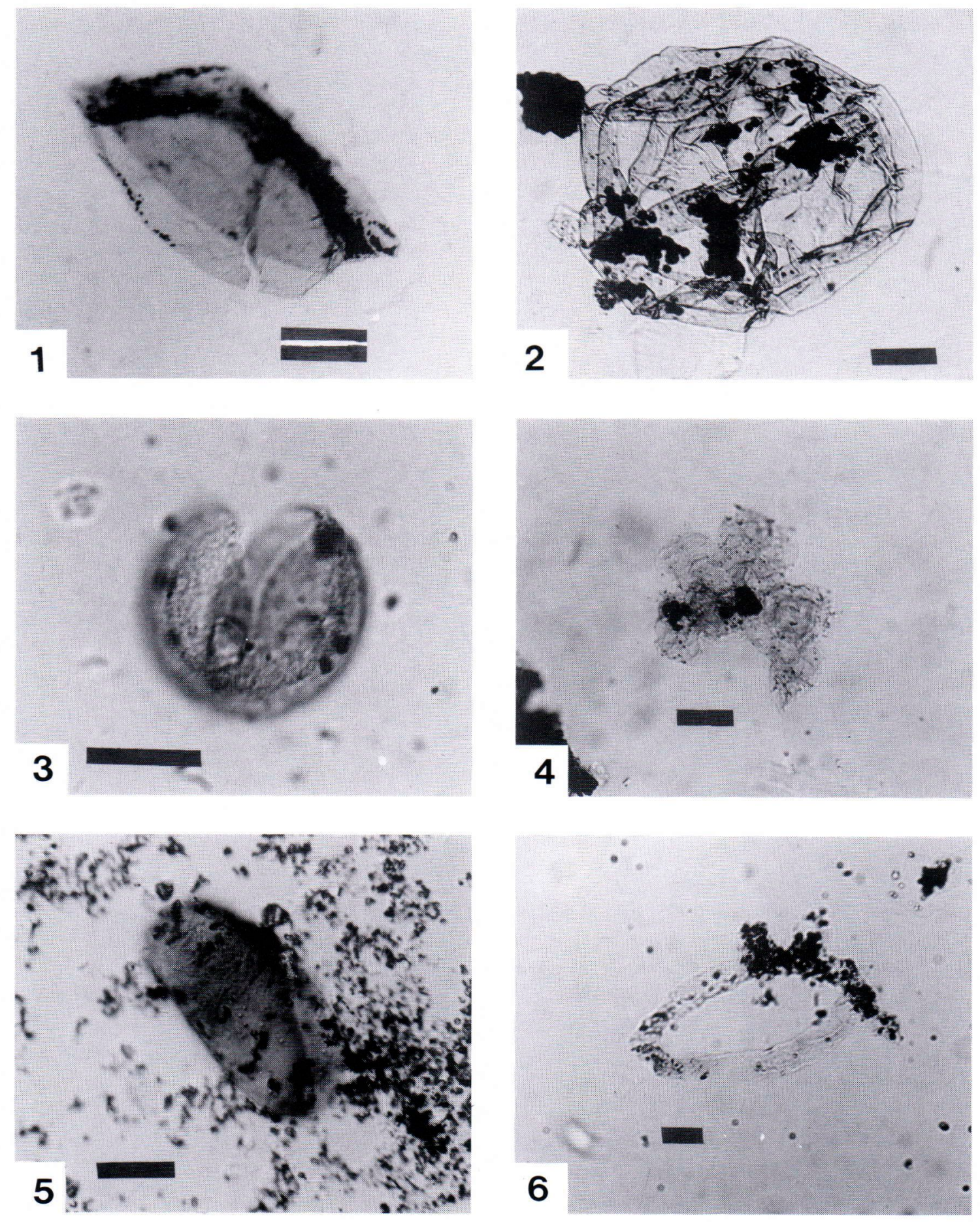

Pl. I. 1. Microfossils from the Lappajärvi sedimentary rocks. 1-2 Sphaeromorphs, 3. thick-walled sphaeromorph, 4. coenobia, 5. ovoid and 6. fragment of filament. Bar equals $10 \mu \mathrm{m}$, double bar $100 \mu \mathrm{m}$. 